\title{
Constituent Power and Constitutionalism in 19th Century Norway
}

\author{
Eirik Holmøyvik
}

\section{Contents}

1 What Is a Constitution? Delegation, Octroi or Contract? ................................................ 276

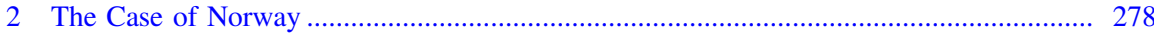

3 Background: The Constituent Power and the Norwegian 1814 Constitution.................... 279

3.1 The 1814 Constitutional Assembly as the Embodiment of the

3.2 International Context and Influences ................................................................. 282

4 Context: The Constituent Power in Post 1814 Restoration Era Europe ............................ 283

4.1 The Monarchical Principle and the Constituent Power............................................. 283

4.2 The Monarchical Principle and the Separation of Powers ...................................... 286

5 Who Is the Constituent Power? Norwegian Constitutionalism Contested 1824-1884 .... 287

5.1 The Monarchical Principle Introduced to Norway ................................................. 287

5.2 Contract or Delegation? Competing Views on the Constitution's Character ........... 291

5.3 The Constituent Power as an Argument for Judicial Review ................................... 295

5.4 The Royal Veto Put to the Test........................................................................ 299

5.5 The Impeachment Case of 1883-1884 ……...................................................... 301

5.6 The Constituent Power Decided .................................................................. 304

6 Conclusion

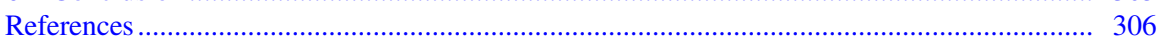

\begin{abstract}
The Norwegian 1814 constitution became in the middle of the nineteenth century an intellectual battleground between the constitutional ideals of the French revolution on the one hand, and the constitutional ideals of the restoration era on the other hand. According to the former understanding, the constitution was meant as an instrument of delegation from the sovereign people as pouvoir constituant to the state institutions as pouvoirs constituées. According to the latter understanding, the constitution was a contract for sharing sovereignty between the king and the people. Being an act of rebellion against the Treaty of Kiel, which stipulated that Norway would enter into a personal union with Sweden, the constitution-making process was consistently legitimized with the sovereignty of the people. The Norwegian framers' understanding of constitution was entirely conventional in American and European revolutionary constitutionalism. The constitution was considered by the
\end{abstract}

E. Holmøyvik (ه)

University of Bergen, Bergen, Norway

e-mail: Eirik.Holmoyvik@uib.no

(C) The Author(s) 2018

U. Müßig (ed.), Reconsidering Constitutional Formation II Decisive Constitutional

Normativity, Studies in the History of Law and Justice 12,

https://doi.org/10.1007/978-3-319-73037-0_7 
framers as an instrument of delegation from the people to the state institutions. There was no trace of contract theory in neither the 1814 constitution's text nor the discussions at the constitutional assembly. The Norwegian 1814 constitution did not follow the path European constitutionalism was heading at the time. The post 1814 European constitutions followed the so-called monarchical principle, which rejected the sovereignty of the people and were legitimized by monarchical sovereignty and contract theory. In the early 1820s, the monarchical principle entered the Norwegian constitutional discourse with the question about a kings' absolute veto on laws and constitutional amendments. King Carl Johan attempted to reshape the constitution's system of separation of powers in accordance with the monarchical principle by a series of amendment proposals in 1821 to curb the parliament's power. These spurred an intense public debate in journals and pamphlets and were firmly rejected by the parliament in 1824. After the debates on constitutional reform in the 1820 s a contractual interpretation of the constitution emerged. For the next 60 years, two contradictory interpretations of the 1814 constitution's character existed side-by-side: One based on the sovereignty of the people, the other based on contract theory and the monarchical principle. In the 1860 s, the debate on the constitution's character spilled over into a related issue, namely the uniquely early Norwegian development of judicial review on the constitutionality of laws and administrative acts. Norway was the first country in Europe to develop a consistent and lasting system of judicial review. The Supreme Court's enforcement of the constitution as higher law was grounded in the notion of the constitution being an act of the sovereign people as pouvoir constituant with precedence over laws and administrative acts, being only decisions of delegated authority by pouvoirs constituées. In the 1870 s the long debated issue of the royal veto was be put to the test and triggered a political crisis. The king claimed an absolute veto on constitutional amendments, after the parliament adopted an amendment allowing government ministers to attend debates in the parliament. The liberal majority in the parliament rejected the royal veto with reference to the sovereignty of the people. In 1883 the crisis reached its climax as impeachment proceedings were instituted against the government for violating the constitution. In 1884 the Court of Impeachment finally pronounced that the constitution did not allow the king to veto constitutional amendments, and that the exercise of such a veto violated the constitution. The Court's decision also settled the debate on the constitution's character as it firmly rejected the contractual interpretation and instead entrenched the 1814 constitution in the constitutional ideals of the French revolution.

\section{What Is a Constitution? Delegation, Octroi or Contract?}

What kind of legal instrument is a constitution? In the nineteenth century, the answer to this basic ontological question would produce conflicting replies depending on where, when and who you asked. Particularly so in Norway, where 
this question underpinned the constitutional debate for most of the century and shaped Norwegian constitutionalism to be arguably the most progressive in contemporary Europe. The topic of this chapter is the competing views on the constitution's legal character in nineteenth century Norway.

In the first decade of the century, at the eve of the revolutionary era, constitutions were, formally at least, considered acts of the sovereign people delegating public authority to the various branches of government. This was, and indeed still is, a defining feature of the modern written constitution following the American and French revolutions in the late eighteenth century. ${ }^{1}$

The notion of the constitution as an instrument of delegation was most clearly stated in the French 1791 constitution in Title 3 Art. 2 on the public powers:

«La Nation, de que seule émanent tous les Pouvoirs, ne peut les exercer que par délégation.»

The nation was the sovereign, but could only exercise its sovereign authority through delegation. The constitution then went on to delegate ("délégué") the legislative power to an elected and representative National Assembly, while the executive power was delegated to the king through his ministers, and lastly, the judicial power was delegated to judges elected by the people. ${ }^{2}$

We find the same notion of constitution in the American state constitutions of the 1770 s and 1780s, though somewhat less clearly pronounced. The first modern written constitution, the celebrated constitution of Virginia from 1776, states in Section 2 of its influential Bill of Rights:

«That all power is vested in, and consequently derived from, the people; that magistrates are their trustees and servants, and at all times amenable to them.»

Both documents refer to the fundamental distinction-famously coined for posterity by the French abbé Emmanuel-Joseph Sieyès in 1789-between the people as pouvoir constituant and the branches of government as pouvoirs constitués, deriving their authority from the former through an act of delegation and set out in a written constitution. ${ }^{3}$

Constitutional development is however neither linear nor is it monolithic. On the European continent the radical constitutional experiments of the 1790 s were rather short-lived due to Napoleon's defeat in 1814 and the subsequent monarchical restoration and numerous constitutions following the Congress of Vienna in 18141815. From the second decade of the nineteenth century and for several decades to follow, the answer to the question posed above would often be that a constitution is an act of royal authority - an octroi in contemporary terminology. Other post-1814 constitutions could be and indeed were considered contracts between the monarch

\footnotetext{
${ }^{1}$ See Dippel (2005).

${ }^{2}$ See The French constitution of 1791 Titre 3 Art. 3-5.

${ }^{3}$ See the 1789 pamphlets Qu'est-ce que le Tiers État and Préliminaire de la Constitution in Sieyès (1994[1789], 161 and 198-199).
} 
and the people or the estates for sharing sovereignty and distributing political rights and obligations between them.

The question of the constitution's legal-ontological character was effectively a question of sovereignty and who possessed it: ${ }^{4}$ The people, the monarch, or both by virtue of what Carl Schmitt has called a "Verfassungsvertrag"? 5

What, if any, was the practical significance of these conflicting views on the constitution's legal-ontological character? An immediate consequence concerned constitutional amendment. If the constitution was an instrument of delegation enacted by the sovereign people, then only the people through a special procedure involving the constituent power could amend the constitution and its terms of delegation. Moreover, according to the distinction between the constituent power and constituted powers, the people's representatives in parliament could not amend the constitution by an ordinary legislative act, since that was an act of a constituted power by virtue of the authority granted by the constitution. The constitution thus had precedence over legislative acts. If on the other hand the constitution was an act of royal authority, then the monarch could amend or replace it as well. The monarch would then serve in a dual capacity as both the constituent power and as the head of the executive branch. Lastly, if the constitution was a contract between the monarch and the people or the estates, then amendment to the contract would usually require the assent of both parties to the contract. Here, the distinction between the constituent and constituted powers would be blurred by the fact that both the monarch and the parliament or the estates would also act in the capacity of constituted powers.

\section{The Case of Norway}

Norway adopted its constitution on 17 May 1814, at a time when the source of legitimacy of European constitutions was shifting from the sovereignty of the people in the constitutions of the 1790s to the monarchical principle or contractual foundations in the post-1814 constitutions. Stuck in an ideological limbo, Norwegian lawyers debated for decades on the constitution's legal-ontological character and its relation to the post-1814 European constitutions. One issue was more contested and sharpened the positions more than any other, namely constitutional amendment. Specifically: Did constitutional amendments require the king's sanction to be valid? On this question, the constitution's text was silent, causing lawyers and politicians on both sides to resort to arguments of the constitution's character.

In the following we shall see how the debates on the royal veto on constitutional amendment divided Norwegian lawyers and politicians between two fundamentally

\footnotetext{
${ }^{4}$ On the juridification of national sovereignty by means of constitutions, see Müssig (2016).

${ }^{5}$ Schmitt (1928, 63-64).
} 
different understandings of the 1814 constitution's legal character (Sect. 5). This division moreover unveiled an ideological divide between the Norwegian 1814 constitution and European constitutionalism following the Congress of Vienna. ${ }^{6}$ We shall also see how the Norwegian Supreme Court's pioneering development of judicial review of the constitutionality of laws, as the first court in Europe, was framed in notion of the constitution as an instrument of delegation on behalf of the sovereign people (Sect. 5.3). First however I will provide some context by discussing the notion of constitutional amendment in the eyes of the Norwegian 1814 constitution's framers (Sect. 3), and thereafter its post-1814 European constitutional and political context (Sect. 4).

\section{Background: The Constituent Power and the Norwegian 1814 Constitution}

\subsection{The 1814 Constitutional Assembly as the Embodiment of the Constituent Power}

How did the framers of the Norwegian 1814 constitution view its legal character, and how did they understand constitutional amendment? This question may be answered with relative certainty when we take into account the constitution's background, wording and context.

If we first consider the constitution's background, we find the at the time familiar pattern of an elected constitutional assembly deliberating on and adopting the constitution. The Norwegian constitution-making process in 1814 was consistently legitimised with reference to the sovereignty of the people and its prerogative of adopting a constitution.

First of all, the constitution was an act of rebellion against the Treaty of Kiel, concluded between the king of Denmark and Norway and the king of Sweden on 14 January 1814. Denmark and Norway had formed a union under one king since 1319. The Treaty of Kiel broke the union by stipulating that Norway was to be transferred to the Swedish monarch. The Norwegians responded to the treaty by declaring independence by way of adopting a constitution. The Swedish claims that Norway's independence and constitution violated the Kiel Treaty were rejected by the Norwegians with reference to the sovereignty of the people and its right to decide its own constitution. ${ }^{7}$ The same reasoning was applied when crown prince Christian Frederik, acting as regent in Norway and now taking on the leadership in the rebellion, intended to seize the Norwegian throne by right of inheritance. His

\footnotetext{
${ }^{6}$ On the distinctive character of Norwegian 19th century constitutionalism compared to Europe, see Holmøyvik (2016a).

${ }^{7}$ See Mestad (2014).
} 
claims too were firmly rejected by leading Norwegian officials and academics with the same reasoning as for the Swedish claims.

Secondly, the constitutional assembly was considered at the time as the embodiment of the people's constituent power. After his failed attempt to seize the throne by virtue of inheritance, Christian Frederik issued a call for the election of a constitutional assembly on 19 February 1814. In the call he stressed that that the nation's elected representatives should decide Norway's form of government, and crucially, that his anticipated accession to the Norwegian throne would depend on the constitution eventually adopted. ${ }^{8}$ In other words, he as former heir to the Norwegian throne and now leader of the provisional government would have no say in the constitution's adoption. That was the prerogative of the sovereign people acting through the constitutional assembly.

Turning to the 1814 constitution itself, unlike many preceding European and American constitutions, the Norwegian constitution does not contain lofty references to the sovereignty of the people or other general principles. These principles were of course well known by the framers, but the constitutional assembly deliberately left references to general principles out of the constitutional text. ${ }^{9}$ This leaves us to search for the framers' fundamental view on constitutional amendment in the constitution's operative provisions.

Art. 112 deals with constitutional amendment. ${ }^{10}$ The official 1814 translation into English reads:

This Constitution, when sanctioned by the National Assembly [the constitutional assembly], becomes the fundamental law of the Kingdom.

If experience should prove, that any part of it ought to be altered, a proposal concerning that affair shall be made in an ordinary session of the National Assembly [the parliament] and be published in print. But it is the business of the next National Assembly to decide, whether the alteration proposed shall take place or not. Yet such an alteration must never be inconsistent with the principles of this fundamentel [sic] law, but only concern modifications in particular cases, which do not alter the spirit of this Constitution, to which alteration the consent of two thirds of the National Assembly is required. ${ }^{11}$

Keeping in mind the distinction between the constituent power and constituted powers, the constitution's amendment procedure is noteworthy in two respects.

Firstly, the constitution was adopted by an elected representative assembly with the one task of writing and adopting the constitution. This fact is also stressed at the end of the document, preceding the signatures of the 112 representatives at the

\footnotetext{
${ }^{8}$ See Holmøyvik $(2012,417)$.

${ }^{9}$ See Aall $(1859,409)$.

${ }^{10}$ Article 110 in the constitution adopted on May 17 1814, but renumbered to article 112 in the revised constitution of November 4 1814. To avoid confusion, I refer to both as article 112.

${ }^{11}$ The Constitution of the Kingdom of Norway. Jacob Lehmann: Christiania 1814. In the English translation, the distinction between the constitutional assembly ("Rigsforsamlingen") in the first paragraph and the parliament ("Storthinget") in the second paragraph has been lost in translation. In the Norwegian language original, paragraphs one and two distinguish between the constitutional assembly competent to adopt the constitution, and the procedure to amend it.
} 
constitutional assembly, where it was stated that the "Deputies of the Kingdom of Norway, hereby declare this Constitution, sanctioned by the National Assembly, to be the fundamental law of the Kingdom of Norway". ${ }^{12}$

Secondly, future constitutional amendments were to be adopted by the parliament with a two thirds majority, but only after a general election. This mechanism is significant in two respects: The intervening general election involves the sovereign people directly in constitutional amendment. Moreover, the king is given no role in constitutional amendment. The king's absence is significant as constitutional amendment then is left altogether to the people through the representatives in parliament and, in theory, through the direct manifestation of the popular will in a general election.

On the king's role the constitutional amendment procedure differed from the ordinary legislative procedure, where the constitution Art. 79 provided the king with a suspensive veto modelled on the French 1791 constitution. For the framers in 1814 , the enactment of constitutional law and ordinary laws were to fundamentally different acts not to be confused. ${ }^{13}$ One was an act of the constituent power acting as sovereign, the other the act of a constituted power. The distinction between the two was fundamental and clear for everyone at the time. Two examples may illustrate this conviction.

At one point during the deliberations of the constitutional assembly some representatives wanted to extend the assembly's deliberations to policy issues like foreign affairs. To this suggestion one of the assembly's leading members, Christian Magnus Falsen, successfully reminded the assembly that it was not permitted to exercise legislative or executive powers, since it operated on the specific authority on the sovereign people to write and adopt a constitution. ${ }^{14}$

Another example is from the constitution's revision on 4 November 1814 to accommodate a personal union with Sweden. The Norwegian rebellion against the Treaty of Kiel had failed, resulting in a short war with Sweden. The cease fire agreement with the Swedish king, the Convention of Moss of 14 August, allowed Norway to keep its with constitution with the necessary amendments to accommodate a personal union with Sweden. In the negotiations that ensued, the Swedes argued that the new union king would have to consent to the revised constitution. This was the contractual understanding of constitution. The Norwegian parliament however, sitting in an extraordinary session for the purpose of revising the constitution, made it plain that "the constitution, according to its nature, cannot be part of those laws which require a royal sanction to become law". ${ }^{15}$ For the framers,

\footnotetext{
${ }^{12}$ The Constitution of the Kingdom of Norway. Jacob Lehmann: Christiania 1814.

${ }^{13}$ For an in-depth discussion on the framers' view on constitutional amendment, see Holmøyvik (2012, 492-517).

${ }^{14}$ See the records of the constitutional assembly on April 18, 1814 in Riksforsamlingens forhandlinger. 1914. Vol. 1. Kristiania: Grøndahl \& søns boktrykkeri, 116-117.

${ }^{15}$ Translated from the records of the extraordinary parliament in Det overord. St. Forh. (1814, 427-428).
} 
then, there was no inconsistency in denying the king any involvement in constitutional amendment, while granting him a suspensive veto in the enactment of laws.

\subsection{International Context and Influences}

Considering the wider intellectual context, until 1814 the Norwegian framers' understanding of constitution was entirely conventional in American and European constitutionalism. ${ }^{16}$ The same distinction between constitutional amendment and legislation was found in the monarchical French 1791 and Spanish 1812 constitutions. Neither of them gave the monarch any say in constitutional amendment, yet they awarded him a suspensive veto on legislation. Republican constitutions too distinguished conceptually and institutionally between constitutional amendment and legislation. American constitutions of the 1770s and 1780s and European constitutions from the 1790 s adopted different approaches to constitutional amendment. Some constitutions, like the 1780 Massachusetts constitution, made constitutional amendment a prerogative of a specifically elected constitutional assembly, others, like the Spanish 1812 constitution and the 1790 constitution of South Carolina, allowed the ordinary parliament to adopt amendments after an intervening general election. Other constitutions again, like the French 1791 constitution, combined both a constitutional assembly and the ordinary parliament. The most radical approach was to leave the adoption of constitutional amendments to the sovereign people directly by voting in the primary assemblies. In Europe the 1798 Batavian constitution is one example of this model, in America the $1792 \mathrm{New}$ Hampshire constitution is another.

What all these constitutions have in common is the notion of the constitution as an instrument of delegation from the sovereign people as constituent power to the branches of government as constituted powers, as proclaimed unequivocally in the French 1791 constitution and in the 1776 Virginia Bill of Rights, both quoted above. Important protagonists for this idea, apart from the above-mentioned Sieyès, include Thomas Paine in the 1791 The Rights of Man and Emer de Vattel in the 1758 Droit de Gens. ${ }^{17}$

Of the more than 130 constitutions ${ }^{18}$ written between 1776 and the adoption of the Norwegian constitution on 17 May 1814, there are in fact very few exceptions to the said scheme. Arguably the sole notable exception is the Swedish 1809 constitution, which provided the monarch with an absolute veto in both legislation and constitutional amendment. Owing largely to the uniquely Swedish evolutionary constitutional tradition at the time, this constitution did not subscribe to the ideology and form of the constitutions that followed from the American and French revolution.

\footnotetext{
${ }^{16}$ See Holmøyvik (2012, 241-245).

${ }^{17}$ See Paine (1894[1791], 428) and de Vattel (1758, 34-37).

${ }^{18}$ Estimate based on the list of historical constitutions at www.modern-constitutions.de.
} 
The Norwegian constitutional assembly were well acquainted with foreign constitutions and relied heavily on them in its work. We find numerous traces of borrowing from contemporary constitutions in the final constitutional text, in particular the French 1791 constitution and the Swedish 1809 constitution, but also other French and European constitutions as well as both the American federal constitution and state constitutions.

The Norwegian framers in 1814 were however not unfamiliar with the notion of the constitution as a contractual instrument. The English constitution was commonly considered a contract between the king and the people, and as such it was conveyed as a general model to a European public by celebrated writers like Charles de Montesquieu in the 1748 De l'esprit des lois and Jean-Louis de Lolme in the 1771 Constitution de l'Angleterre. ${ }^{19}$ Both Montesquieu and de Lolme described the English constitution as a contractual relation between the king, the nobility and the commons. For both Montesquieu and de Lolme, but most explicitly stated by the latter, the aim of the English constitution, facilitated by its separation of powers system, was to put the said three powers in perfect equilibrium. As a result, the king, the nobility and the commons in their respective assemblies, all would have to consent to the formation of laws. Among the Norwegian framers, de Lolme was held in particular esteem and he was quoted extensively in the introduction to the most important private draft to the constitution. ${ }^{20}$ Nonetheless, the Norwegian framers deliberately rejected his principal idea of a royal veto to maintain equilibrium.

The framers were also well acquainted with the Swedish 1809 constitution, and indeed used some parts of it as a direct model for the 1814 constitution. Crucially though they did not adopt the Swedish constitution's contractual elements like the royal veto on legislation and constitutional amendments.

The fact that there is no trace of contract theory in neither the 1814 constitution's text nor the discussions at the constitutional assembly, allows us to safely conclude that the framers considered the constitution as an instrument of delegation. The practical result of this understanding was that only the people could amend the constitution. This understanding was codified in Art. 112 of the constitution.

\section{Context: The Constituent Power in Post 1814 Restoration Era Europe}

\subsection{The Monarchical Principle and the Constituent Power}

Despite its many borrowings from foreign constitutions, the Norwegian 1814 constitution did not follow the path European constitutionalism was heading at the

\footnotetext{
${ }^{19}$ See Montesquieu (1961[1748], 163-174, book 11 Chap. 6) and de Lolme (1771).

${ }^{20}$ See the draft of Johan Gunder Adler and Christian Magnus Falsen in Riksforsamlingens forhandlinger. 1916. Vol. 3. Kristiania: Grøndahl \& søns boktrykkeri, 3-8.
} 
time. As the Norwegian constitutional assembly laboured on its constitution in the spring of 1814, another constitution project was under way in France. This constitution, the Charte constitutionnelle, was granted by the newly instated king Louis XVIII on 4 June, only 18 days after the adoption of the Norwegian constitution. The Charte is a significant event in European constitutional history as it heralded and served as model for a new European constitutional order in an era of monarchical restoration after decades of revolutions and the Napoleonic wars. ${ }^{21}$

European constitutional discourse following the Charte was influenced by the so-called monarchical principle. ${ }^{22}$ The monarchical principle was a political slogan directed against the revolutionary constitutional ideology of the previous decades. Already in 1804-1806, the German philosopher Friedrich Schlegel had called for a "monarchisches Princip" to provide the state with stability. ${ }^{23}$ The monarchical principle did not however entail the return to the Ancien Régime and the rejection of the essentials of modern constitutionalism introduced by the constitutions following the American and French revolutions, like the separation of powers, representative government or the acknowledgment of certain individual rights. These principles were also implemented in the post-1814 monarchical constitutions and in the Charte. After the French revolution there was no going back to absolutism, and the Charte stated in its preamble that it recognised the progress of the Enlightenment and the major intellectual changes which it had brought forth. ${ }^{24}$

The Charte and the monarchical principle did however reject the sovereignty of the people as the source of legitimacy for a constitution. This rejection of popular sovereignty created a fundamental rupture between pre and post-1814 European constitutionalism. The Charte and many subsequent European constitutions in the following decades were instead octroyed, which meant that they were granted by the monarch by virtue of his sovereign authority. According to its preamble, the Charte was granted "par le libre exercice de notre autorité royale", making it an "OCTROI à nos sujets". For many German states, monarchical sovereignty even became an international law obligation pursuant to Art. 57 in the 1820 Wiener Schlußakte regulating the German Confederation established by the Congress of Vienna in 1815 . The monarchical principle was moreover enforced militarily by the Great Powers, acting through treaty systems like the Holy Alliance and the Quintuple Alliance, and authorising interventions in Naples and Spain in the 1820s to suppress threats to monarchical rule.

\footnotetext{
${ }^{21}$ On the model character of the Charte Constitutionnelle 1814, see i.e. Müssig (2012).

${ }^{22}$ On the monarchical principle, see Böckenförde (1991), Stolleis (2001, 61-63) and Reinhardt (2000, 426-431).

${ }^{23}$ Schlegel (1837, 331-332).

${ }^{24}$ See the preamble to the Charte: «Nous avons dû, à l'exemple des rois nos prédécesseurs, apprécier les effets des progrès toujours croissants des lumières, les rapports nouveaux que ces progrès ont introduits dans la société, la direction imprimée aux esprits depuis un demi-siècle, et les graves altération qui en sont résultées [...].».
} 
In addition to the octroyed constitutions, a number of the post-1814 constitutions were presented as contracts between the monarch and the people or the estates. One example is the constitution of Württemberg of 1819 , which stated in its preamble:

Durch freie Uebereinkunft [sic] mit den Ständen des Landes ist das Grundgesetz des Staates zu Stande gekommen, das schönste Denkmal der Eintracht zwischen dem König und Seinem Volke.

In German constitutional discourse, the distinction between octroyed constitutions and contractual constitutions was the subject of much debate during the first half of the eighteenth century. ${ }^{25}$ In principle, octroyed and contractual constitutions are fundamentally different in relation to sovereignty and the authority to adopt a constitution. ${ }^{26}$ In practice however, even octroyed constitutions becomes functional contracts if they require the consent of both the monarch and the people or the estates for constitutional amendments. In such a case, even an octroyed constitution would irrevocably limit the very sovereignty the monarch exercised when he adopted the constitution in the first place. The fact that octroyed constitutions limited the exercise of monarchical authority is an essential distinction compared to the absolute monarchies of the Ancien Régime. ${ }^{27}$ Indeed, German legal scholars in the early nineteenth century also considered octroyed constitutions as contracts, as only popular consent was an essential requirement for a "wirkliche Verfassung". 28 The key question for defining the nineteenth century constitution's legal-ontological character is thus not how a constitution was adopted, but how it could be amended. As such, most monarchical constitutions in nineteenth century Europe were either formally or functionally contracts for sharing sovereignty.

The contractual notion of constitution appears to dominate European constitutional discourse in the first half of the nineteenth century. The 1831 Belgian constitution illustrates the pervasive influence of the monarchical principle in this respect. Unlike its contemporaries, this constitution presented itself as an instrument of delegation for the sovereign people in the same flamboyant manner as the French 1791 constitution. Not only did the Belgian constitution proclaim that all power flowed from the nation (Art. 25), it also expressly stated that the king possessed only those powers formally attributed to him by the constitution (Art. 78). In other words, the nation was presented as the constituting power delegating authority to the king and the parliament as constituted powers. The institutional system the constitution established was however a contractual one, in the sense that both the king and the parliament had to approve constitutional amendments (Art. 131) as well as ordinary legislation. The Belgian 1831 constitution may have been dressed

\footnotetext{
${ }^{25}$ See Stolleis $(2001,58-61)$.

${ }^{26}$ See Grimm (2001: 100-141 on 123-124).

${ }^{27}$ An example on the constitution binding the monarch's sovereign authority is the 1818 constitution of Baden Article 5: "Der Grossherzog vereiniget in sich alle Rechte der Staatsgewalt, und übt sie unter den in dieser Verfassungsurkunde festgesetzten Bestimmungen aus."

${ }^{28}$ Grimm (2001: 100-141 on 123). See also Schmitt (1928, 63-64).
} 
in the robes of the revolutionary radicalism of the $1790 \mathrm{~s}$, but underneath its radical veil we find the monarchical principle naked and clear. ${ }^{29}$

\subsection{The Monarchical Principle and the Separation of Powers}

The monarchical principle also had consequences for the constitutions' institutional arrangement and distribution of powers. Whereas pre-1814 constitutions typically placed the legislative power undivided to the people's representatives in a representative assembly, post-1814 constitutions like the Charte returned to Montesquieu and de Lolme's ideal of institutional equilibrium between the monarch, the nobility and the people as the object for the separation of powers. At the core of this institutional equilibrium was the legislative veto power of both the monarch and the nobility in the legislative assembly's upper chamber.

Only days after the adoption of the Norwegian constitution, on 24 May 1814 the influential Swiss political theorist Benjamin Constant restated the theory of equilibrium for the nineteenth century constitutional monarchy in his Réflexions sur les constitutions, la distribution des pouvoirs, et les garanties, dans une monarchie constitutionnelle, aptly subtitled Equisse de constitution. ${ }^{30}$ Constant's innovation was the institutional separation between the monarchical power ("pouvoir royal") and the executive power ("pouvoir exécutif") directed by government ministers. ${ }^{31}$ Freed from the executive, Constant elevated the monarch to what he called a neutral power ("pouvoir neutre") in the state, which specific function was to maintain the balance between the legislative, executive and judiciary in order to provide stability to the state. In Constant's system, the monarch would check the executive by his right to appoint and dismiss ministers, while the judiciary would be controlled by appointments as well as the monarch's prerogative to pardon. To check the legislative, Constant provided the monarch with the right to appoint members of the aristocratic upper chamber, while excesses by the representative lower chamber could be checked by the monarch by his right to dissolve the parliament and by a royal veto on legislation.

Constant's institutional arrangement and distribution of powers was fundamentally different from pre-1814 monarchical constitutions like the French of 1791 or the Spanish of 1812 as well as the Norwegian of 1814. Whereas Constant's system in accordance with the monarchical principle placed the monarch above the other branches of government, the pre-1814 constitutions in accordance with

\footnotetext{
${ }^{29}$ See also Dippel $(2005,153-169$ on 164$)$, who refers to the Belgian constitution as a "masterpiece of constitutional camouflage".

${ }^{30}$ See Constant (1814).

${ }^{31}$ On Constant's theory of separation of powers, see Vile (1998, 224-227) and Holmøyvik (2012, 536-538).
} 
notions of popular sovereignty typically made the representative parliament the institutional centre. In these constitutions, the monarch and the executive played second fiddle, while aristocratic upper chambers were abolished altogether. The Charte and other monarchical European constitutions in the subsequent decades, including later constitutions like Italy's Statuto Albertino of 1848 and the Danish constitution of 1849, were however largely in accordance with Constant's Equisse de constitution.

This brief outline shows that the Norwegian 1814 constitution was from the outset out of step with the constitutional developments Europe guided by the monarchical principle. As we shall see in the following, the Norwegians were soon to discover their constitutional solitude, and it was to become a source of contention for the next seventy years.

\section{Who is the Constituent Power? Norwegian Constitutionalism Contested 1824-1884}

\subsection{The Monarchical Principle Introduced to Norway}

In the early 1820 s, the monarchical principle entered the Norwegian constitutional discourse and disrupted the constitutional unity from 1814. This shift from the sovereignty of the people to the monarchical principle is nicely illustrated by the already mentioned Christian Magnus Falsen. He is often referred to as the father of the 1814 constitution due to his leading role at the constitutional assembly and due to the highly influential draft constitution he authored with the Dane Johan Gunder Adler. Falsen's draft constitution, which became the single most important direct source to the 1814 constitution, ${ }^{32}$ opened with 32 basic principles, two of which concerned constitutional formation and amendment:

$\S 10$. Since the purpose of every society is: the happiness of all; since government is instituted to secure man the enjoyment of his natural rights, then only the people as a whole, through its representatives, may constitute its government.

$\S 11$. On the same grounds, the people have the right to, according to specific intervals and rules, to review and improve on the constitution; though so that what was once considered its essence, may not be changed. The current generation cannot impose its laws upon future generations. ${ }^{33}$

These two articles borrowed heavily from the 1780 Massachusetts declaration of rights (Art. 7) and the 1793 French declaration of rights (Art. 28). Their message was clear: The people are the constituent power and only the people through their representatives can adopt and amend a constitution. The same was true for the

\footnotetext{
${ }^{32}$ See the list of direct sources to the 1814 constitution in Höjer $(1882,195)$.

${ }^{33}$ Riksforsamlingens forhandlinger. 1916. Vol. 3. Kristiania: Grøndahl \& søns boktrykkeri, 10. My translation.
} 
specific constitutional amendment procedure in Falsen's draft constitution. Here, all amendments were first to be proposed by an elected constitutional assembly ever 25 years, and then voted on by the people directly in the primary assemblies. ${ }^{34}$ The king, to whom the draft constitution provided a suspensive veto on legislation, was not given any role in constitutional amendment in Falsen's draft constitution.

Ten years later, in 1824, Falsen wrote the following in a pamphlet:

Concerning amendments to the constitution, then presumably the king has already an absolute veto, and there is thus nothing left to discuss concerning this part of the argument. ${ }^{35}$

Here Falsen presented a contractual view on the constitution, the very opposite of his position in 1814, and importantly, squarely contrary to the constitutional assembly's position that year. Why this radical turnaround?

The immediate occasion for the royal veto's comeback in Norwegian constitutional discourse was the union king Carl Johan's attempt to re-shape the constitution's system of separation of powers by a series of amendment proposals in 1821. The king argued that the 1814 constitution did not provide a "perfect equilibrium" between the branches of government, and that the scales were in fact tipped in the parliament's favour. ${ }^{36}$ The king was moreover concerned-unfounded it later turned out - that the Holy Alliance might take notice of the radical Norwegian constitution and use military force to supress it like it did in Naples the same year. ${ }^{37}$

In order to restore constitutional equilibrium and to bring Norway into line with European restoration constitutionalism the king proposed in 1821 a number of amendments meant to curb the parliament's power. One of the amendment proposals would give the monarch the right to dissolve the parliament. Montesquieu had argued that the executive's right to dissolve parliament was required to maintain equilibrium. ${ }^{38}$ The framers in 1814 had like most pre-1814 constitutions denied the executive this competency, while the Charte and other post-1814 monarchical constitutions had re-introduced it.

The by far most important and controversial amendment proposal concerned the introduction of an absolute royal veto on legislation. The monarch's absolute veto on legislation was the cornerstone of Montesquieu and de Lolme's separation of powers systems aimed to produce equilibrium. Rejected by the Norwegian framers in 1814, the absolute veto was an essential feature in the later European octroyed and contractual constitutions. It was also a key component in Benjamin Constant's conception of the monarch as a neutral power to guarantee stability.

\footnotetext{
${ }^{34}$ See article 228 in the draft, in Riksforsamlingens forhandlinger. 1916. Vol. 3. Kristiania: Grøndahl \& søns boktrykkeri, 56.

${ }^{35}$ Falsen (1824a, 20). My translation and italics.

${ }^{36} \mathrm{My}$ translation of the royal proposition included in the parliamentary records of 1821 , see St. Forh. (1821, vol. 7, 685).

${ }^{37}$ See Nielsen $(1873,108-109,175-176,181)$.

${ }^{38}$ See Montesquieu (1961[1748], 169, book 11 Chap. 6).
} 
Incidentally, Constant had served as Carl Johan's adviser in 1813-1814. At that time the former French plebeian, who rose to general in Napoleon's armies and eventually to Marshal of France before in 1810 being offered to succeed Charles XIII of Sweden, had considered making an attempt on the French throne. ${ }^{39}$ We do not know however if Constant's constitutional theory influenced Carl Johan directly in 1821 , or if he simply followed the pattern set by the new monarchical constitutions in Europe. Nonetheless, Carl Johan's view on the monarch's constitutional role resembled Constant's notion of a neutral power above the three branches of government. As he set forth his constitutional amendment proposals in 1821, Carl Johan argued that such amendments, including an absolute royal veto on legislation, were required for the king to "guard the nations' rights". 40

The king's amendment proposals spurred an intense public debate in journals and pamphlets. It was during this debate that Christian Magnus Falsen, who supported the king's reform, claimed that the constitution already granted the king an absolute veto on constitutional amendment. As late as in 1818, Falsen had published a commentary to the constitution where he made no mention of a royal veto on constitutional amendments. ${ }^{41}$ Falsen's change of heart may have been triggered by the king's call for a constitutional reform, but his call for a stronger executive may also been due to his outspoken scepticism of the substantial representation of farmers in the Norwegian parliament. The combination of a large number of freeholders in Norway and quite liberal voting qualifications in the 1814 constitution awarded voting rights to around $45 \%$ of all male citizens above the age of 25 , including a substantial part of the peasantry. ${ }^{42}$ At the first session of the parliament in 1815 , roughly one third of the representatives were from the peasantry, while in 1833 almost half of the representatives were of this class. ${ }^{43}$ In 1821 Falsen himself unsuccessfully proposed a reform of the parliament in order to reduce the number of farmers eligible and to restrict admission to the parliament's upper chamber.

Even though an absolute veto on constitutional amendments was not on the table in the contested amendment proposals, nobody could fail to notice that the king and his supporters championed a new notion of constitutionalism compared to the constitutional assembly in 1814 . This new constitutionalism emphasised monarchy and contractualism instead of the sovereignty of the people. The absolute royal veto on constitutional amendments was only a corollary to this new notion of constitution.

Falsen and the king's supporters made no secret of the source of their novel constitutional interpretation. In one of his pleas for the absolute veto, Falsen attributed his new view on the constitution to "the monarchical principle, on which

\footnotetext{
${ }^{39}$ On the relation between Constant and king Carl Johan, see Hasselrot (1950, 9).

${ }^{40}$ Quoted from the parliamentary records of 1824 where the constitutional amendment proposals of 1821 are included, see St. Forh. (1824. Vol. 2, 40). My translation.

${ }^{41}$ See Falsen $(1818,181-184)$.

${ }^{42}$ See Kuhnle (1972).

${ }^{43}$ See Mohn (1874).
} 
so much is written these days". ${ }^{44}$ During the debate in 1824 , the king's supporters made frequent references to the monarchical principle, to its implementation in the post-1814 European constitutions and to the Holy Alliance's enforcement of restoration constitutionalism. ${ }^{45}$

The novelty of these constitutional arguments was recognised and criticised by the opponents of the king's amendment proposals. They accused the king transforming the constitution based upon the sovereignty of the people into a contract between the king and the people - in other words turning the 1814 constitution into a post-1814 European restoration constitution.

In the end, the king's amendment proposals, including his demand for an absolute veto on legislation, were firmly rejected by the parliament on the very symbolic date of 17 May 1824. For the Norwegian parliament, the rejection of the king's reform was also a matter of defending Norway's independence in the personal union with Sweden. The Norwegians rightly feared that a strengthened executive in the hands of the union king seated in Stockholm, could lead to Swedish influence on Norwegian affairs and institutions.

Concerning the specific grounds for a constitutional reform, a unanimous standing committee for constitutional affairs rejected the king's claims that the legislative and executive branches were imbalanced in the 1814 constitution. Yet in order not to provoke the king, the committee's report was carefully worded and devoid of any discussion of the monarchical principle. At the very end of the report, the committee even stated that the king, according to the nature of things, did enjoy an absolute veto on constitutional amendment. ${ }^{46}$ The committee gave no reasons for the statement and it was not considered significant at the time. Since the veto on legislation and constitutional amendments had been considered interrelated in the preceding debate, the committee's statement is surprising and contradicts its conclusion on the legislative veto. Most likely, the committee's acknowledgement of a royal veto on constitutional amendment was intended to sugar the report's rejection of the constitutional reform. ${ }^{47}$

The preceding debate was however a taste of what was to come. The arguments made on the monarchical principle were seeds of a new understanding and reinterpretation of the constitution among conservatives and other supporters of the monarchy in the decades to come. From now on, there would be no unity among Norwegian lawyers and politicians on sovereignty and the 1814 constitution's legal-ontological character.

\footnotetext{
${ }^{44}$ Quoted and translated from Falsen's anonymous article with the title "On the Absolute Veto" on March 18, 1824 in the journal Tilskueren.

${ }^{45}$ On the debates in 1821-1824, see Holmøyvik (2013).

${ }^{46}$ See St. Forh. (1824, Vol. 2, 108-109).

${ }^{47}$ Most commentators have interpreted the committee's statement in the same way, see Castberg (1964, 327) and Kaartvedt (1964, 283).
} 


\subsection{Contract or Delegation? Competing Views on the Constitution's Character}

The parliament's rejection in 1824 of the king's constitutional reform effectively blocked any major reform of the constitution's separation of powers until the end of the century. King Carl Johan persisted however in his demand for an absolute veto on legislation, and put forth constitutional amendment proposals to this effect at every session of the parliament until 1839, but to no avail. Yet even though the avenue to formal amendment was blocked, the constitution's interpretation continued to be disputed.

The most contested question was the royal veto on constitutional amendment. The king claimed to have such a right, and indeed exercised it by sanctioning constitutional amendments passed by the parliament. On six occasions between 1818 and 1863 the king refused to sanction amendments passed by parliament. In all six cases the parliament respected the royal vetoes. It is not clear however whether the parliament did so in order not to provoke conflict with the king or if it acknowledged a royal veto on constitutional amendments. ${ }^{48}$

Since the framers in 1814 considered constitutional amendment a prerogative of the people through their representatives in the parliament, the constitution's text did not make any reference to the king in this respect, not to speak of a royal veto. As a result of the text's silence on the matter, any argument for a royal veto on constitutional amendment would have to be based on an interpretation of the constitution's character or fundamental principles rather than the text. With the debate that followed the king's proposed constitutional reform in the early $1820 \mathrm{~s}$, two distinct interpretations of the 1814 constitution materialised in Norwegian constitutional doctrine.

The first commentaries to the 1814 constitution, by law professor Henrik Steenbuch in 1815 and Christian Magnus Falsen in 1818, before the latter succumbed to the monarchical principle, held that the parliament alone could amend the constitution. ${ }^{49}$ At this time, the monarchical principle appears to have been unknown in Norway, and these early commentaries followed the constitution's text closely.

After the debates on constitutional reform in the 1820s however, a contractual interpretation of the constitution emerged. A treatise on Norwegian public law from 1830 held simply and without reasoning that the constitution was a "pact and contract between the king and the people, and which cannot be amended without the consent of both parties to the contract". 50 Consequently, the king's veto followed from the constitution's contractual character, not the constitution's wording. The author, lawyer and politician Fredrik Georg Lerche, did however add a footnote

\footnotetext{
${ }^{48}$ For an overview of cases, see the faculty of law's 1881 report on the royal veto in Sth. Prp. No. 20 (1881), 29.

${ }^{49}$ See Steenbuch (1815) and Falsen $(1818,181-184)$.

${ }^{50}$ Lerche $(1830,53)$. My translation.
} 
where he made reservations to the validity of this "common assumption" if subjected to further scrutiny. Still, Lerche's treatise does indicate that a contractual interpretation of the constitution had become commonplace by 1830 .

At this time, Benjamin Constant's constitutional doctrine of the king as a neutral power to balance the three branches of government influenced Norwegian constitutional doctrine. A widely read constitutional law pamphlet written by the military officer Nicolai Tidemand and published in 1829, referred to Constant and argued for a separation of the monarch from the government in order to establish the monarch as a neutral power with an absolute veto on legislation. ${ }^{51}$ In a 1834 , the philosopher Niels Treschow similarly called for a constitutional reform with reference to Constant's model, including an absolute royal veto on legislation and the establishment of a true upper chamber in the parliament. ${ }^{52}$ However, Treschow was hesitant in recommending an absolute royal veto on legislation as long as Norway was part of a personal union with Sweden. ${ }^{53}$ Like the parliament in 1824, he feared Swedish influence on Norwegian institutions.

From the 1830s and 1840s, these two opposing interpretations of the Norwegian constitution were grounded in more coherent theories on constitutional formation.

In 1833, the young university lecturer Frederik Stang published the first systematic treatise on Norwegian constitutional law. ${ }^{54}$ Stang's treatise was the most comprehensive, important and influential presentation of Norwegian constitutional law until the 1870s. In his 1833 treatise, Stang specifically addressed the constitution's legal-ontological character and its relation to European post-1814 constitutionalism.

According to Stang, the Norwegian 1814 constitution was fundamentally different from most contemporary European constitution as it was neither octroyed nor a contract between the king and the people. While Stang acknowledged that the contractual notion of constitution was dominant in Europe, he explained to the reader that the Norwegian 1814 constitution subscribed to a different kind of constitutionalism as it was adopted "at a time when the people did not recognize any monarchical power, only its own sovereignty". ${ }^{55}$ The time Stang had in mind was the revolutionary constitutionalism of the 1790s, when constitutions were held to be acts of delegation by the sovereign people. According to Stang, the Norwegian 1814 constitution was precisely such a constitution and the people alone were sovereign. As a result, the king could not have an absolute veto on constitutional amendment, although Stang allowed for a suspensive veto by analogy of

\footnotetext{
${ }^{51}$ See Tidemand (1829, 76-114).

${ }^{52}$ See Treschow (1839).

${ }^{53}$ In Tidemand's pamphlet, published posthumously, the publisher Jonas Anton Hielm, a former attorney general and liberal politician, added similar concerns over the absolute veto in a separate postscript to the pamphlet, see Tidemand $(1829,130-131)$.

${ }^{54}$ See Stang (1833).

${ }^{55}$ Stang (1833, 654 and 31).
} 
the king's veto on legislation. ${ }^{56}$ A suspensive royal veto was however impossible to reconcile with the text in the constitution's amendment clause. As a result, Stang's interpretation on this point gained few followers. ${ }^{57}$

Stang also addressed the possible constitutional consequences of the negotiations with Sweden in the autumn of 1814 for revising the constitution to accommodate a personal union with Sweden. Did the negotiations on the constitutional revision turn the constitution into a contract between the union king and the Norwegian people? Stang rejected all such claims, as he concluded that the constitutional revision was minor and that it did not in any way alter the constitution's fundamental character as an act of the people acting as the constituent power through the constitutional assembly in $1814 .^{58}$

While Stang emphasised the historical context of the Norwegian 1814 constitution to distinguish it from subsequent octroyed and contractual European constitutions, others called instead for the constitution to be interpreted in light of and accordance with the monarchical principle and contemporary European constitutionalism. The most influential reinterpretation of the Norwegian constitution was later attorney general Bernhard Dunker's Om den Norske Constitution ("On the Norwegian Constitution 1814") published in $1845 .^{59}$

Dunker's reinterpretation of the constitution was a response to a comprehensive commentary to the constitution published earlier that year and written by the liberal lawyer Peder Krabbe Gaarder. Like Stang in 1833, Gaarder rejected a contractual interpretation of the constitution and emphasised the sovereignty of the people as the constitution's basic and guiding principle contrary to most contemporary European constitutions:

[...] our entire constitution as a product of the sovereignty of the people, and [is] also founded upon this principle, which is perhaps more extensively implemented in our constitution than in any state with a monarchical form of government. ${ }^{60}$

As a result of this understanding of the constitution, Gaarder denied the king any veto, suspensive or absolute, on constitutional amendment. His was a classical 1790s style understanding of constitutional formation. In Gaarder's system, the king was only a constituted power, while constitutional amendment was a prerogative of the people as the constituent power.

Bernhard Dunker on the other hand, rejected such a historical interpretation of the 1814 constitution. According to Dunker, the Norwegian constitution had to be interpreted with regard to the constitutional development in Europe after its adoption in 1814 and thus according to the monarchical principle. ${ }^{61}$ Dunker found a

\footnotetext{
${ }^{56}$ See Stang (1833, 639-642).

${ }^{57}$ See also Ræder $(1841,80)$, Hjelm (1863, 91-92) and Höjer (1882, 139-146).

${ }^{58}$ See Stang (1833, 33-34 and 639-642).

${ }^{59}$ See Dunker (1845).

${ }^{60}$ Gaarder (1845). My translation.

${ }^{61}$ See Dunker $(1845,2)$.
} 
textual basis for his reinterpretation in the constitution's article 1, which stated that the "form of government is a limited and hereditary monarchy". 62

Before Dunker, the phrase "limited ... monarchy" in Art. 1 of the constitution was commonly understood in its historical context as a rejection of monarchical sovereignty and absolutism, which the 1814 constitution abolished. Between 1661 and 1814, the kingdom of Denmark-Norway had been an absolute monarchy, the only of its kind governed by a written constitution, the Lex Regia of 1665. The constitutional commentaries of Steenbuch in 1815, Falsen in 1818, Gaarder in 1845 and Stang's 1833 treatise, all held that Art. 1 was a reference to the separation of powers, in which monarchy was limited by democracy through an elected parliament. $^{63}$

Dunker on the other hand, reading the constitution through the lens of the monarchical principle, interpreted the words "limited ... monarchy" as an expression of monarchical sovereignty:

The constitutional meaning of the phrase, saying that the form of government is limited monarchical, is really that all public authority is vested in the monarch, although he may be limited in its exercise, so that he in certain matters may not act without the consent of the parliament, this does not really deprive him of any part of it. ${ }^{64}$

According to Dunker, the monarch, not the people, was the source of sovereignty and thus all public authority, limited only by the constitution. Dunker's novel interpretation of the Norwegian constitution was nothing but a mirror-image of provisions in German restoration constitutions proclaiming monarchical sovereignty. The 1818 Bavarian constitution, for example, contained the following provision, that may very well have influenced Dunker:

Der König ist das Oberhaupt des Staats, vereiniget in sich alle Rechte der Staatsgewalt, und übt sie unter den von Ihm gegebenen in der gegenwärtigen Verfassungs-Urkunde festgesetzten Bestimmungen aus. ${ }^{65}$

Having established monarchy as the source of all public authority, Dunker went on to systematically reinterpret the constitution according to the monarchical principle.

A complete reinterpretation was not possible however due to the constitution's clear wording on key issues. Art. 49 proclaimed unequivocally that the legislative power resided in the people through the parliament, while Art. 79 made it clear that the king only had a suspensive veto in legislation. These facts Dunker simply dismissed as an error made by the framers in 1814 due to their inexperience. Like

\footnotetext{
${ }^{62}$ The Constitution of the Kingdom of Norway. Jacob Lehmann: Christiania 1814.

${ }^{63}$ See Steenbuch $(1815,11-12)$, Falsen $(1818,6)$, Stang $(1833,49-50,64)$ and Gaarder $(1845,11)$. ${ }^{64}$ Dunker $(1845,4)$. My translation and italics.

${ }^{65}$ The constitution of Bavaria of 1818 Titel II art. 1. My italics. See similar provisions in the constititions of Baden of 1818 art. 5, Württemberg of 1819 Chap. 2 art. 4, Hesse-Darmstadt of 1820 art. 4, Saxe-Coburg-Saalfeld of 1821 art. 3, Saxony of 1831 art. 4, Hesse-Cassel of 1831 art. 10, Brunswick of 1832 art. 3, Hohenzollern-Sigmaringen of 1833 art. 3 and Hanover of 1833 art. 1.
} 
Montesquieu, de Lolme, Constant as well as king Carl Johan in 1821, Dunker argued that an absolute veto was a constitutional necessity in order to maintain the equilibrium between the branches of government. ${ }^{66}$ Moreover he argued that the "very concept of monarchy" in Art. 1 of the constitution demanded an absolute royal veto on all decisions made by the parliament. ${ }^{67}$ As evidence, he pointed to the fact that the absolute royal veto was found in all monarchies save for Norway.

Dunker's method was thus to reshape the Norwegian constitution in the image of European restoration constitutionalism. The same method was applied on constitutional amendment. Here, article 112 in the constitution did not expressly bar an absolute royal veto as it made no mention of the king at all. The text's silence allowed Dunker to argue that the king already possessed an absolute veto by virtue of the constitution's basic principle and fundamental contractual character. ${ }^{68}$ Whether or not the 1814 constitution was an actual contract between the king and the people was beyond the point. For Dunker, the constitution was a functional contract in the sense that sovereignty flowed from the king to be shared by the people in the manner decided by the constitution. According to this understanding of constitution, a monarchical constitution simply could not be amended by the people alone.

\subsection{The Constituent Power as an Argument for Judicial Review}

The debate on the constitution's character concerned primarily, but not solely the royal veto on constitutional amendments. It also spilled over into a related issue, namely the uniquely early Norwegian development of judicial review on the constitutionality of laws and administrative acts. ${ }^{69}$ This issue too concerned constitutional amendment in the sense that it placed the courts as the supreme interpreters and guardians of the constitution. In the 1860 s, the people as the constituent power and the specific understanding of the constitution as an instrument of delegation became an important argument to legitimatise judicial review.

Judicial review of the constitutionality of laws was introduced by the US Supreme Court in the celebrated judgement Marbury v. Madison in $1803 .^{70}$ In France, Emmanuel Joseph Sieyès' had proposed the establishment of a jury

\footnotetext{
${ }^{66}$ See Dunker (1845, 95-97).

${ }^{67}$ See Dunker $(1845,92)$.

${ }^{68}$ See Dunker $(1845,126-127)$.

${ }^{69}$ For an English language account of the historical development of judicial review in Norway, see Kierulf (2014). For the Norwegian development in a Nordic perspective, see Helgadóttir (2006) and Rógvi (2013). In the Nordic languages, see Sunnqvist (2014), Holmøyvik and Michalsen (2015, 326-361 and Smith (1993).

${ }^{70} 5$ U.S. 137 (1803).
} 
constitutionnaire already in $1795,^{71}$ and a similar constitutional review of legislative acts was introduced in the 1799 constitution. ${ }^{72}$ However, the French system of constitutional review was abolished in 1814 by the adoption of the Charte constitutionnelle. Moreover, it was not a true ex post judicial review by the courts, but rather an ex ante review by one of the legislative bodies, the Sénat conservateur. On this background, Norway was the first country in Europe to develop a consistent and lasting system of judicial review of legislation and administrative acts.

Despite having no provision which explicitly granted the court's competence to review the constitutionality of laws and administrative acts, the 1814 constitution was from its adoption considered as positive law to be enforced by the branches of governments, including the courts. As early as in 1822 we find the first known case before the Supreme Court concerning legislation violating the constitution. In 1818 the parliament had adopted a law regulating the sale of copper from a specific mine. As a direct consequence of the law, a number of civil servants in the area lost income stipulated in their employment contracts by imposing fees on the sale of copper. The law itself did not provide compensation for the civil servants' loss. The majority in the Supreme Court however, awarded the civil servants compensation with reference to the constitution's Art. 105 which required full compensation for expropriation as well as the prohibition of retroactive laws in Art. 97.

Even though the Supreme Court in the 1822 case shied away from explicitly declaring the law unconstitutional, the case is still an example of the constitution taking precedence over ordinary laws and thus judicial review exercised by a court. The law was considered constitutional only if the plaintiffs were awarded compensation for the violation of their constitutional rights. The Supreme Court adopted the same approach in review cases in 1841, two cases in 1844, 1854, 1855 and $1862^{73}$

Until 1863, the grounds for Supreme Court judgements were not made public. Moreover, the grounds were usually terse and without any discussion of the legitimacy and scope of judicial review. In 1866 the Supreme Court decided another review case, in which a majority of four justices found that an 1857 law on conscription was unconstitutional unless the plaintiff, a naval officer, was compensated for additional workload imposed by the law. This time Peder Carl Lasson, chief justice for 18 years between 1855 and 1873, felt compelled to address the principle of judicial review. In a separate opinion, he wrote:

How shall the Supreme Court rule, when at the same time the constitution and ordinary laws are submitted to it? As far as I know constitutional law doctrine, in such cases it is generally agreed, that since one cannot instruct the courts to rule according both laws at the same time, then they must necessarily give preference to the constitution $[\ldots]^{74}$

\footnotetext{
${ }^{71}$ See Sieyès (1939).

${ }^{72}$ See The French constitution of 1799 art. 21.

${ }^{73}$ For a detailed discussion of these review cases, see Smith (1993, 78-110).

${ }^{74}$ The judgement is published in Ugeblad for lovkyndighed, statistik og statsøkonomi. Vol. 6. 1866-1867, 165-174 on 172.
} 
Lasson's wording and reasoning is similar to that of his American colleague chief justice John Marshall in the 1803 case Marbury v. Madison. ${ }^{75}$ Due to Lasson's principled and explicit stand on judicial review, the 1866 judgement has become known as Norway's Marbury v. Madison. According to Lasson, the constitution had precedence over ordinary laws, but his opinion did not provide any reasons other than a general consensus on the matter.

In the 1850s and 1860s, the Supreme Court's competence to exercise judicial review and its legitimacy was publically debated in Norway. ${ }^{76}$ The majority of lawyers and legal scholars accepted that the Supreme Court had the competence to exercise judicial review, but there was less agreement on its scope. There were also critics, like the Danish law professor Johannes Nellemann, who in 1868 criticised judicial review as incompatible with "the nature of constitutional monarchy" as it involved the judicial branch in politics. ${ }^{77}$ In 1869 , chief justice Lasson published a supplement to his 1868 treatise on criminal procedure where he addressed the legitimacy of judicial review in more detail than in his opinion in the 1866 judgement. $^{78}$

Lasson made a number of arguments for the legitimacy of judicial review. ${ }^{79}$ His point of departure was the separation of powers, to which he considered judicial review of legislation and administrative acts as an essential component in order to protect the individuals' constitutional rights from legislative and executive intervention. He also endorsed the development of judicial review in the United States, and referred to Joseph Story's discussion of judicial review in the 1833 Commentaries on the Constitution of the United States. ${ }^{80}$ The similarities between Lasson's separate opinion in the 1866 case and Marshall's opinion in Marbury v. Madison were thus not incidental.

In addition to these arguments, Lasson also addressed the 1814 constitution's character and the distinction on this point between the Norwegian constitution and other European constitutions.

According to Lasson, judicial review by the Supreme Court was legitimate due to the distinction between the constitutive and the constituted powers in the 1814 constitution. For him, the understanding of the 1814 constitution as an act of delegation rather than a contract was essential to the legitimacy of judicial review. Lasson argued that the constitution had to take precedence over laws since "the

\footnotetext{
75" So if a law be in opposition to the constitution; if both the law and the constitution apply to a particular case, so that the court must either decide that case conformably to the law, disregarding the constitution; or conformably to the constitution, disregarding the law; the court must determine which of these conflicting rules governs the case. This is of the very essence of judicial duty." $5 \mathrm{U}$. S. 137 (1803, 178).

${ }^{76}$ On the early Norwegian debates on judicial review, see Slagstad (2011, 367-392).

${ }^{77}$ Nellemann $(1868,113)$. My translation.

${ }^{78}$ See Lasson (1869).

${ }^{79}$ For an in-depth discussion of Lasson's reasoning, see Holmøyvik and Michalsen (2015, 341-346).

${ }^{80}$ See Story $(1833,425$ pp.).
} 
constituent power in article 112 of the constitution is superior to the legislative, the executive and the judicial power". ${ }^{81}$ Thus judicial review and the constitution's supremacy over legislation was only a natural and necessary consequence of the distinction between constitutive and the constituted powers.

Lasson also addressed the fact that in Europe, judicial review was unique to Norway. Like Stang in 1833, Lasson made it clear that the Norwegian 1814 constitution was fundamentally different from the octroyed constitutions in other European monarchies as these were contracts involving both the king and the people in constitutional amendment. ${ }^{82}$ His reasoning seems to be that judicial review of a contractual constitution might not be legitimate, since the courts as a third party would then interfere in the contract between the king and the parliament. If on the other hand the constitution was an act of delegation from the sovereign people as the constituent power, then judicial review was legitimate since the parliament and the king as constituted powers could always resort to

the remedy prescribed by the constitution itself in article 112 , that is to appeal to the sovereignty of the people - the highest tribunal possible in a free form of government, $[\ldots] .{ }^{83}$

To emphasise this point, Lasson referred to the famous French political scientist and historian Alexis de Toqueville and his celebrated De la démocratie en Amérique from $1835 .{ }^{84}$ In his study of the American democracy, Toqueville was both puzzled and enchanted by the American judicial system and in particular judicial review. His observation as to how judicial review was possible in the United States and not in his native France, was that

[i]n America the Constitution rules both legislators and simple citizens. It is therefore the primary law and cannot be modified by law. Hence it is right that the courts should obey the Constitution rather than all the laws. ${ }^{85}$

In other words, in the United States the constitution was an act of delegation by the sovereign people as the constituent power and thus superior to the laws adopted by the constituted powers. Toqueville also pointed to the fact that unlike in France, where the Charte constitutionnelle of 1830 was octroyed and unamendable, the constitution of the United States could be amended by the people through a procedure designated in the constitution. This distinction between the French and the American constitutions led Tocqueville to conclude that judicial review by American courts would not put sovereignty in the hands of the judges as the people could ultimately amend the constitution. This was exactly Lasson's point too when he referred to the amendment procedure in Art. 112 in the constitution as an appeal to the sovereignty of the people.

\footnotetext{
${ }^{81}$ Lasson $(1869,18)$. My translation.

${ }^{82}$ Lasson $(1869,20)$.

${ }^{83}$ Lasson $(1869,18)$. My translation.

${ }^{84}$ See Lasson $(1869,18)$.

${ }^{85}$ Toqueville (1966[1835], 123).
} 
By referring to Toqueville, Lasson identified the Norwegian 1814 constitution with the republican 1787 constitution of the United States. At the same time he distinguished it from the octroyed and contractual monarchical constitutions in Europe.

Other lawyers too argued like Lasson for judicial review as an appeal to the sovereign people as the constituent power. ${ }^{86}$ Yet there appears to be no causal link between the understanding of the 1814 constitution as an act of delegation and the acceptance of judicial review. Prominent defenders of the royal veto on constitutional amendments, like law professors L. M. B. Aubert and Torkel Halvorsen Aschehoug (see Sect. 5.5) also accepted the Supreme Court's development of judicial review. ${ }^{87}$

For the topic of this chapter however, it is sufficient to conclude that the chief justice Lasson formulated his famous separate opinion in the landmark 1866 case on the specific understanding of the constitution as an instrument of delegation from the sovereign people as the constituent power.

\subsection{The Royal Veto Put to the Test}

The scholarly debate on the royal veto on constitutional amendment concerned abstract notions of monarchy and sovereignty, yet this question had a very real political significance: a royal veto could block any constitutional reform initiated by the parliament. As long as the king continued to sanction constitutional amendments, or the parliament respected a royal veto, open conflict between the king and the parliament was kept at bay. Eventually, though, in the increasingly uneasy relationship between the king and the parliament, a constitutional reform was destined to be considered existential by both parties. The unresolved constitutional dispute would then turn into a political crisis in which the existence of a royal veto would be put to the test. That crisis came in the 1870 s and reached its climax in 1884 with the entire government being convicted in the Court of Impeachment.

Starting in the mid-nineteenth century, the liberal fraction in the parliament pushed for constitutional reforms to strengthen the parliament and to increase popular influence in public matters. As a result of this campaign, annual sessions in the parliament were finally introduced by a constitutional amendment in $1869,{ }^{88}$ voting rights were expanded in 1884 and a constitutional amendment in 1862 allowed for the introduction of juries in criminal cases, which were finally introduced by the Criminal Procedure Act of 1887.

\footnotetext{
${ }^{86}$ See Andresen (1862). See also Slagstad $(2011,385)$.

${ }^{87}$ See Aubert $(1864,41)$.

${ }^{88}$ According to the 1814 constitution, parliament was assembled only three months every three years, though in practice the parliament remained assembled for longer periods. In 1863 the king had refused to sanction a constitutional amendment for annual parliaments.
} 
At the same time, the liberal fraction also campaigned for an amendment of article 74 in the constitution to allow government ministers to attend debates in the parliament. The aim was to put government ministers under increased parliamentary control and scrutiny by forcing them to justify the government's policies directly before the parliament. According to Art. 12 in the 1814 constitution, the government ministers were the king's personal advisers and appointed and dismissed at his will. Even though the amendment of Art. 74 would not provide the parliament with any formal control over the government and its composition, the king and his supporters rightly feared that its adoption would be a first and decisive step towards a full-blown parliamentary system. ${ }^{89}$ The parliamentary system was an existential threat to the king and his government, as it meant that a government would live and die on the mercy of the parliamentary majority instead of the king. This constitutional amendment was thus conceived by its opponents as an attempt to dismantle the separation of powers system in the 1814 constitution and to shift the balance of power radically in favour of the parliament.

In 1872 the parliament, where the liberal fraction enjoyed a large majority, adopted an amendment of article 74 to allow government ministers to attend debates in the parliament. Not surprisingly, the king refused to sanction and proclaim the amendment, claiming an absolute veto. In order to exhaust any argument of a two times suspensive veto by analogy of the king's legislative veto like Stang claimed in 1833, the parliament then adopted in 1874, 1877 and in 1880 identical amendments after three consecutive general elections. Again, the king refused to sanction and proclaim the amendments. In 1880 however, after the third consecutive adoption of the amendment and the king's subsequent refusal to sanction and proclaim it, the parliament responded by adopting a resolution declaring the constitutional amendment valid without royal sanction.

The parliament's rejection of the royal veto in 1880 sparked the most serious political crisis in Norway since the struggle for independence in 1814. The king and his government, led by prime minister Christian August Selmer, considered a coup d'état and made certain military preparations. ${ }^{90}$ In response, supporters of the liberal majority in the parliament organised militias all over the country to defend the parliament. The extreme political tensions are vividly illustrated by the famous playwright and later Nobel laureate in literature Bjørnstjerne Bjørnson, who in a speech published in 1882 openly threatened with civil war if the king would not respect the "decision of the sovereign people". 91

In the end, the issue would be settled in court. In the 1882 general election the liberal fraction won a landslide victory. This allowed them to win majority in the parliament's lower chamber as well as all seats in the upper chamber. Their strategy was to convict the government in the Court of Impeachment, to which the

\footnotetext{
${ }^{89}$ For an overview of the subsequent development of a parliamentary system with emphasis on its constitutional status, see Holmøyvik (2016b).

${ }^{90}$ See Hagemann $(2005,167-168)$.

${ }^{91}$ Bjørnson (1882, 12). My translation.
} 
parliament's lower chamber could institute a prosecution. Since the Court of Impeachment was composed of nine supreme court judges and seventeen members of the parliament's upper chamber, the well organised liberal fraction could effectively dictate the outcome of the proceedings. On 18 May 1883, impeachment proceedings were instituted against the government for violating the constitution by advising the king to refuse to sanction the 1880 constitutional amendment. ${ }^{92}$ The indictment thus presupposed that the constitution did not allow the king to veto constitutional amendments, and that the exercise of such a veto violated the constitution.

\subsection{The Impeachment Case of 1883-1884}

The impeachment proceedings were preceded by an intense public debate from the mid-1870s following the king's refusals to sanction the contested constitutional amendments on the government ministers. While the liberals enjoyed a large majority in the parliament, the country's judicial elite sided predominantly with the king and the government. At the government's request, the faculty of law at the university of Christiania (Oslo), the country's only university at the time, published a comprehensive report on the royal veto in 1881. The six law professors concluded unanimously that the constitution provided the king with an absolute veto on constitutional amendments. ${ }^{93}$ The report became the mainstay of the campaign for the royal veto, yet it did little to deter the liberals in their pursuit of the contested constitutional amendment.

The public debate and the impeachment proceedings cultivated the arguments and positions from the preceding scholarly debate. As the constitution's text was open on the issue - it neither expressly prohibited nor allowed for a royal vetoarguments for and against the royal veto, and thus also the impeachment case, hinged upon the understanding of the constitution's basic character: If the constitution was an actual or functional contract between the king and the people, then a royal veto on constitutional amendments naturally followed from its contractual character. If on the other hand the constitution was an act of delegation from the sovereign people as constituent power, then a royal veto was logically impossible as

\footnotetext{
${ }^{92}$ The government was also charged on two other minor counts for not executing two parliamentary decisions. One of them concerned the financing of militias directed against the king and the government.

${ }^{93}$ The faculty of law's 1881 report is published in Sth. Prp. No. 20 (1881). One of the professors, Frederik Brandt, agreed on the conclusion, but dissented on the reasoning. Brandt dismissed all the report's arguments for the royal veto, in effect saying that the constitution did not provide a royal veto on constitutional amendments. Still he agreed with the report's conclusion since he considered a royal veto on constitutional amendments to be a natural consequence of a monarchical form of government.
} 
the king was only a constituted power acting on authority delegated to him by the constitution.

After nearly 60 years of discussion, these two opposing views on the constitution were now clearly articulated and subject of a heated public debate dominating political life in Norway for more than a decade before being settled by the Court of Impeachment. What were the arguments?

The point of departure for the liberal fraction in the parliament and the prosecutor in the impeachment case was that the constitution "is not a pact between people and king, but a constituent act, by which the people can determine its constitution by virtue of its sovereignty". ${ }^{94}$ Here we clearly see the understanding of the constitution as an instrument of delegation. This claim was supported by historical sources intended to prove that the omission of the king in the constitution's amendment procedure in Art. 112 was no mistake or oversight by the framers, but rather a deliberate move motivated by the understanding of the constitution as an act of delegation from the sovereign people. Moreover, this argument was supported by a historical-contextual interpretation of the constitution. The parliamentary majority and its supporters pointed to the framers being influenced by the constitutional doctrine and constitutions following the American and French revolution and based upon the sovereignty of the people. ${ }^{95}$ In the impeachment proceedings, the prosecutor argued that the constitution had to be interpreted in light of preceding constitutions like the United States Constitution of 1787, the French constitution of 1791, the Batavian constitution of 1798 and the Spanish constitution of $1812 .{ }^{96}$ The constitutional amendment procedure in all of these constitutions, though different in the details, followed the same basic model as the Norwegian constitution by involving the parliament and the people, but not the executive branch (see Sect. 3).

For the king and his supporters, the constitution was a contract in the sense that its basic principle was that "sovereignty shall be divided between the branches of government in equal measures", according to the conclusion in the faculty of law's 1881 report. ${ }^{97}$ Yet a contractual argument for shared sovereignty was sensitive to historical criticism, as it was clear and not contested that the constitution was adopted by the constitutional assembly in 1814 by virtue of the sovereignty of the people. To get around the constitution's historical context the king and his supporters resorted to two lines of reasoning, both intended to prove that subsequent events had transformed the constitution into a contract.

\footnotetext{
${ }^{94}$ The citation is from the liberal majority in the parliament's standing committee for scrutiny in 1878, quoted from the parliamentary records, see Indst. O. IV. 1878, 17.

${ }^{95}$ A key study is Berner (1878).

${ }^{96}$ See the records of the Court of Impeachment in 1883-1884 in Rigsrets-Tidende. 1883-1884. 3. Vols. Vol. 2. Kristiania: Th. Steens Forlags-Expedition, 85-89.

${ }^{97}$ Quoted from the faculty of law's 1881 report in Sth. Prp. No. 20 (1881), 39. My translation. The same argument was made by the defender in the impeachment case, see in Rigsrets-Tidende. 1883-1884. 3. Vols. Vol. 2. Kristiania: Th. Steens Forlags-Expedition, 505.
} 
One line of reasoning challenged the liberals' historical interpretation by emphasising the constitution's revision in the autumn of 1814. The negotiations between the Norwegian parliament and the Swedish king on the constitution's revision had, the royalists argued, rendered it into an actual contract between the parliament and the king. ${ }^{98}$ However, as seen in Sect. 3, the extraordinary parliament revising the constitution in the autumn of 1814 had explicitly rejected the idea of the revised constitution as a contract. Regardless of the constitution's origins, the king's supporters argued that a royal veto on constitutional amendments had at least been established by constitutional practice and customary law, since the king had in fact sanctioned all constitutional amendments since $1814 .{ }^{99}$

The other and more important line of reasoning was a systemic interpretation of the constitution's separation of powers aimed to prove that it was intended as functional contract. This argument held that while the constitution had indeed been adopted by virtue of the people's sovereignty, the people had then transferred its sovereignty by means of the constitution to the king and the parliament. ${ }^{100}$ There was little historical evidence to support such a claim however. Instead it was based on a deduction from the very concept of separation of powers. For the royalists, separation of powers simply meant Montesquieu's doctrine of equilibrium, in which the royal veto was a key element (see Sect. 4). While there were hardly any references made to Montesquieu at the constitutional assembly in 1814, arguments for the royal veto in the 1870 s and 1880 s were full of references to him. For the royalists, Montesquieu's prestige was so great that at one point in the impeachment proceedings, the defender referred to him as nothing less than "Montesquieu the master". 101

The resurgence of the Montesquieuan doctrine of equilibrium was merged with arguments according to the monarchical principle. During the impeachment proceedings, the defender repeatedly argued that an absolute royal veto on constitutional amendments was nothing more than a corollary of monarchy. ${ }^{102}$ Europe's post-1814 monarchical constitutions were employed to prove the point, although the European constitutional landscape was more diverse now than in the $1820 \mathrm{~s}$. The use of European restoration constitutionalism to interpret the Norwegian constitution can be illustrated with the already mentioned Frederik Stang. In his 1833

\footnotetext{
${ }^{98}$ See i.e. the debate on June 141878 in the parliamentary records, Storthingstidende (1878), vol. 2, 507-522 and the defender in the Court of Impeachment in See examples in Rigsrets-Tidende. 1883-1884. 3. Vols. Vol. 2. Kristiania: Th. Steens Forlags-Expedition, 717.

${ }^{99}$ See the faculty of law's 1881 report in Sth. Prp. No. 20 (1881), 17, 29 and 39 and Aubert (1880, 5-6).

${ }^{100}$ See the records of the Court of Impeachment in 1883-1884 in Rigsrets-Tidende. 1883-1884. 3. Vols. Vol. 2. Kristiania: Th. Steens Forlags-Expedition, 505, the faculty of law's 1881 report in Sth. Prp. No. 20 (1881), 19 and Aubert (1880, 24).

${ }^{101}$ Quoted from the records of the Court of Impeachment in 1883-1884, see Rigsrets-Tidende. 1883-1884. 3. Vols. Vol. 2. Kristiania: Th. Steens Forlags-Expedition, 525.

${ }^{102}$ See examples in Rigsrets-Tidende. 1883-1884. 3. Vols. Vol. 2. Kristiania: Th. Steens Forlags-Expedition, 515-517, 531, 570.
} 
constitutional law treatise, Stang the young scholar had rejected any link between the 1814 constitution and the later octroyed and contractual constitutions of post-1814 restoration Europe. Later however, like Christian Magnus Falsen in the 1820s, Stang changed his view on the royal veto. As prime minister between 1861 and 1880, Stang advised the king to veto the constitutional amendment on the government ministers in 1872, 1874 and 1877. In 1883, the ageing Stang published a pamphlet arguing for the royal veto on constitutional amendments and called for the interpretation of the Norwegian constitution in light of "later monarchical constitutions" in Europe. ${ }^{103}$

\subsection{The Constituent Power Decided}

The proceedings before the Court of Impeachment lasted for almost eleven months until 1 April $1884 .{ }^{104}$ The written records from the proceedings span three volumes with a total of around 2900 pages. ${ }^{105}$ In the end, the Court of Impeachment ruled that the constitution did not allow the king to veto constitutional amendments. Prime minster Selmer and the government ministers were all convicted and most of them dismissed from their offices. ${ }^{106}$

The verdict was political in the sense that the parliamentarian members of the Court of Impeachment all voted for conviction, while the Supreme Court judges all voted for acquittal. The Court was sharply divided on class lines as well. The Supreme Court judges belonged to the nation's traditional ruling class of senior civil servants, like the law professors and government ministers. Among the seventeen parliamentarians, only one was a lawyer, the rest being a motley group of farmers, school teachers and others representing the common people.

Despite the case's political context, the Court of Impeachment in 1883-1884 finally settled the 60-year-old dispute on the royal veto on constitutional amendment and the constitution's character. The sovereignty of the people had prevailed over the monarchical principle. Sovereignty was not divided between the king and the people. The people alone were the constituent power, and the constitution was not a contract for sharing sovereignty, but an instrument of delegation for the sovereign people.

The king and some royalist lawyers, like the leading constitutional law scholar and conservative politician Torkel Halvorsen Aschehoug, refused however to accept

\footnotetext{
${ }^{103}$ Stang (1883, 30-31). My translation.

${ }^{104}$ Due to procedural reasons, the prime minster and the government ministers were indicted individually, leading to separate judgements being rendered from February 27 to April 11884.

${ }^{105}$ Rigsrets-Tidende. 1883-1884. 3. Vols. Kristiania: Th. Steens Forlags-Expedition.

${ }^{106}$ The Court of Impeachment's protocol is published in Dokument nr. 1 (1930) Voteringer $i$ Riksrettene 1814-1884, 109-192. See also Hallager (1915-1916, 101-128).
} 
the judgement as an authoritative interpretation of the constitution. ${ }^{107}$ The conservative press reacted with shock and horror, accusing the liberals for annihilating the 1814 constitution and complaining about the "flood of democracy that has now been released". ${ }^{108}$ The king continued to sanction constitutional amendments, so that in 1913 Art. 112 in the constitution was formally amended as to explicitly ban the royal veto. ${ }^{109}$ Yet after the 1884 judgement by the Court of Impeachment, no subsequent constitutional amendments would be contested with reference to the royal veto. The contractual understanding of constitution was no longer prevalent. Equally important, shortly after the judgement the constitutional amendment on the government minister's access to the parliament went into force. As the king and his supporters had feared, within two decades the presence of government ministers in the parliament had turned into a full-blown parliamentary system. ${ }^{110}$

\section{Conclusion}

Perhaps the Norwegian 1814 constitution was destined to be torn between different interpretations of its basic legal character. Adopted at the very eve of the revolutionary era and modelled on the constitutions following the American and French revolutions, the 1814 constitution was put into effect in a radically different ideological context due to the dominance of the monarchical principle in post-1814 Europe. As a result, two incompatible notions of constitutionalism existed side-by-side in Norway for 60 years until the great clash in 1880-1884.

In the proceedings before the Court of Impeachment in 1883-1884, both sides conjured up terrifying images of their opponent's notion of constitutionalism. For the prosecutor, the contractual understanding of constitution was equal to absolutism. With reference to Montesquieu's doctrine of equilibrium, the prosecutor remarked:

If this system prevails, then clearly the principle of constitutionalism in our constitution is dead. Monarchy would once again and with only minor limitations have won absolute supremacy in the state. ${ }^{111}$

\footnotetext{
${ }^{107}$ See Aschehoug (1893, 565-581) and Morgenstierne (1900, 378-386).

${ }^{108}$ Morgenbladet July 71884.

${ }^{109} \mathrm{~A}$ second paragraph with the following wording was added to article 112: "An amendment to the Constitution adopted in the manner aforesaid shall be signed by the President and the Secretary of the Storting, and shall be sent to the King for public announcement in print as an applicable provision of the Constitution of the Kingdom of Norway." Official translation retrieved from the Norwegian parliament's website: https://stortinget.no/globalassets/pdf/english/constitutionenglish. pdf [accessed 16.09.2016].

${ }^{110}$ For an overview, see Holmøyvik (2016b).

${ }^{111}$ See in Rigsrets-Tidende. 1883-1884. 3. Vols. Vol. 2. Kristiania: Th. Steens Forlags-Expedition, 301. My translation.
} 
The defender for his part referred again and again to the prosecutors arguments as "the constitutional law of the French revolution" and of Rousseau. ${ }^{112}$ More than once the defender alluded to the notorious Robespierre's reign of terror by the guillotine as a certain outcome in Norway too if the people's representatives were left unchecked by a monarch.

Nineteenth century Norway was in many ways an intellectual battleground between the sovereignty of the people and the constitutional ideals of the French revolution on the one hand, and the monarchical principle and the constitutional ideals of the restoration era on the other hand. In Norway, unlike in Europe, the French revolution prevailed.

\section{References}

Aall J (1859) Erindringer som Bidrag til Norges Historie fra 1800 til 1815, 2nd edn. J. W. Cappelen, Christiania

Andresen JP (1862) Om den dømmende Magt. Ugeblad for Lovkyndighed, Statistik og Statsøkonomi 2:358-360

Aschehoug TH (1893) Norges nuværende statsforfatning, 2nd edn., vol 3. Malling, Kristiania

Aubert LMB (1864) Om den dømmende Magts Virksomhed som Kilde til Udviklingen af vor Ret ved Siden af Lovgivningsvirksomheden. Christiania

Aubert LMB (1880) Om det kongelige Veto ved Grundlovsbeslutninger. Kristiania

Berner HE (1878) Folkesouverænitets-principets gjennemførelse i vor grundlov. Nyt norsk Tidsskrift 4:255-304

Bjørnson B (1882) Om Folkesuveræniteten eller det norske Folks Husbondsret. Selskabet for Folkeskrifters Udbredelse, Kristiania

Böckenförde E-W (1991) Recht, Staat, Freiheit. Studien zur Rechtsphilosophie, Staatstheorie und Verfassungsgeschichte. Suhrkamp, Frankfurt am Main, pp 273-305

Castberg F (1964) Norges statsforfatning, 3rd edn, vol 1. Universitetsforlaget, Oslo (2 vols.)

Constant B (1814) Réflexions sur les constitutions, la distribution des pouvoirs, et les garanties, dans une monarchie constitutionnelle. H. Nicolle, Paris

de Lolme J-L (1771) Constitution de l'Angleterre. E. van Harrevelt, Amsterdam

de Vattel E (1758) Droit de gens ou le principe de la loi naturelle, vol 1. London

Dippel H (2005) Modern constitutionalism, an introduction to a history in need of writing. Tijdschrift voor rechtsgeschiedenis 73(1-2):153-169

Dunker B (1845) Om den Norske Constitution. P. J. Hoppes Forlag, Christiania

Falsen CM (1818) Norges Grundlov gjennemgaaet i Spørgsmaal og Svar. R. Dahls Enke og Søn, Bergen

Falsen CM (1824a) Bemærkninger i Anledning af Constitutions-Forslaget om Kongens Veto. Lehmann, Christiania

Falsen CM (1824b) Om det absolutte Veto, Tilskueren, 18 Mar

Grimm D (2001) Verfassung II. Verfassung: zur Geschichte des Begriffs von der Antike bus zur Gegenwart; zwei studien. Duncker \& Humblot, Berlin, pp 100-141

\footnotetext{
${ }^{112}$ See in Rigsrets-Tidende. 1883-1884. 3. Vols. Vol. 2. Kristiania: Th. Steens Forlags-Expedition, 535. My translation.
} 
Gaarder PK (1845) Fortolkning over Grundloven og de øvrige Love, som danne Norges Riges offentlige Ret. J. Chr. Abelsteds Officin, Kristiania

Hagemann G (2005) Det moderne gjennombrudd: 1870-1905. In: Aschehougs Norgeshistorie, vol 9. Aschehoug, Oslo

Hallager G (1915-1916) Norges Høiesteret 1815-1915, vol 2. Aschehoug, Kristiania

Hasselrot B (1950) Benjamin Constant og Bernadotte: De l'esprit de conquête et de l'usurpation og dens tilblivelse. In Festskrift udg. af Københavns universitet i anledning af Hans Majestæt kongens fødselsdag. Bianco Lunos Bogtryggeri, København

Helgadóttir R (2006) The influence of American theories on judicial review in Nordic Constitutional Law. Martinus Nijhoff Publishers, Leiden/Boston

Hjelm CW (1863) Om Grundlovens Principer og den Aand, hvori de under gjensidig Begrændsning ere gjennemførte i dens enkelte Bestemmelser. Feilberg \& Landmark, Christiania

Holmøyvik E (2012) Maktfordeling og 1814. Bergen 2012

Holmøyvik E (2013) Frå revolusjon til restaurasjon. Striden om Grunnlovas vesen 1824-1884. In: Holmøyvik E (ed) Tolkingar av Grunnlova. Om forfatningsutviklinga 1814-2014. Pax Forlag AS, Oslo, pp 307-337, 316-319

Holmøyvik E (2016a) Europe and Norwegian Constitutionalism 1814-2014: from the relationship between Parliament and King to the EEA. In: Müller-Graff P-C, Graver HP, Mestad O (eds) European law and national constitutions. Berliner Wissenschaftsverlag, Berlin, pp 31-48

Holmøyvik E (2016b) Deux siècles de séparation horizontale des pouvoirs en Norvège. Revue française de droit constitutionnel 106:323-333

Holmøyvik E, Michalsen D (2015) Lærebok i forfatningshistorie. Pax Forlag AS, Oslo

Höjer N (1882) Norska grundlagen och dess källor. A. L. Normans Boktryckeri-Aktiebolag, Stockholm

Kierulf A (2014) Taking judicial review seriously: the case of Norway. Faculty of Law, Oslo

Kuhnle S (1972) Stemmeretten i 1814. Historisk tidsskrift, 373-389

Kaartvedt A (1964) Det Norske Storting gjennom 150 år (4 vols), vol 1. Gyldendal, Oslo

Lasson PC (1869) Supplement og Ord- eller Realregister til det i 1868 trykte Skrift om "Straffeprocessen i dens nyeste Skikkelse m. v.". Steen, Christiania

Lerche FG (1830) Kongeriget Norges offentlige Ret. Wulfsbergske Bogtrykkerie, Christiania

Mestad O (2014) Suvereniteten tilbakegitt det norske folk ved Kieltraktaten - det oversedde naturog statsrettsgrunnlaget for norsk sjølvstende og grunnlov i 1814. Historisk tidsskrift 1:35-65

Mohn JN (1874) Storthingene 1815-1874 belyste ved Statistik. Norsk Retstidende, 761-776

Montesquieu C (1961[1748]) De l'esprit des lois (2 vols), vol 1. Ganier Frères, Paris

Morgenstierne B (1900) Lærebog i den norske Statsforfatningsret, 1st edn. Th. Steen, Kristiania

Müßig U (2012) Souveränität um 1813 - Die Nationalsouveränität im Verfassungsdiskurs um die Cortes-Verfassung 1810-1814 und 1820-1823. In: Aschmann B, Stamm-Kuhlmann T (eds) 1813 im europäischen Kontext. Franz Steiner Verlag, Stuttgart, pp 139-161, 147-153

Müßig U (2016) Juridification by Constitution. National Sovereignty in Eighteenth and Nineteenth Century Europe. In: Müßig U (ed) Reconsidering Constitutional Formation I: National Sovereignty. Springer, Berlin, 1-92

Nielsen Y (1873) Grev Sandels's statholderskab 1818-1827. Malling, Kristiania

Nellemann J (1868) Civilprocessens almindelige Deel, 1st edn. Cohens bogtrykkeri, Kjøbenhavn

Paine T (1894 [1791]) The rights of man. In: Conway MD (ed) The writings of Thomas Paine, vol 2. G. P. Putnam's Sons, New York, pp 258-389

Reinhardt W (2000) Geschichte der Staatsgewalt: Eine vergleichende Verfassungsgeschichte Europas von den Anfangen bis zur Gegenwart. C. H. Beck, München

Rógvi K (2013) West-Nordic constitutional judicial review - a comparative study of Scandinavian judicial review and judicial reasoning. DJØF Publishing, Copenhagen

Ræder OM (1841) Den norske Statsforfatnings Historie og Væsen. Andr. Fred. Høst's Forlag, Kjöbenhavn

Schlegel F (1837) Philosophische Vorlesungen aus den Jahren 1804 bis 1806, vol 2. Bonn, Eduard Weber 
Schmitt C (1928) Verfassungslehre, 9th edn 2003. Duncker \& Humblot, Berlin

Sieyès E-J (1939) In: Bastid P (ed) Les discours de Sieyès dans les débats constitutionnels de l'an III. Hachette, Paris, pp 14-44

Sieyès E-J (1994 [1789]) Ecrits politiques. Editions des Archives Contemporaines, Bruxelles, pp 115-188

Slagstad R (2011) Rettens ironi. Studier i juss og politikk, 3rd edn. Pax Forlag AS, Oslo

Smith E (1993) Høyesterett og folkestyret. Universitetsforlaget, Oslo

Steenbuch H (1815) Bemærkninger over Norges Grundlov af 4de November 1814. A. Steen, Trondhjem

Stang F (1833) Systematisk Fremstilling af Kongeriget Norges constitutionelle eller grundlovbestemte Ret. P. J. Hoppes Forlag, Christiania

Stang F (1883) Om den kongelige Sanktionsret efter Norges Grundlov. Aschehoug, Kristiania

Stolleis M (2001) Public law in Germany, 1800-1914. Berghahn Books, New York

Story J (1833) Commentaries on the constitution of the United States (3 vols), vol 3. Hilliard, Gray, and Company, Boston

Sunnqvist M (2014) Konstitutionellt kritiskt dömande: förändringen av nordiska domares attityder under två sekel. Institutet för rättshistorisk forskning, Stockholm

Tidemand N (1829) Om de sammensatte Staters Foreningsmaade tilligemed et politisk Blik paa Regjeringsformene. Jacob Lehmanns Enke, Christiania

Toqueville A (1966 [1835]) Democracy in America (2 vols), vol 1. Harper \& Row, New York Treschow N (1839) Om Norges Grundlov. P. J. Hoppes Forlag, Christiania

Vile MJC (1998) Constitutionalism and the separation of powers, 2nd edn. Liberty Fund, Indianapolis

\section{Records of the Constitutional Assembly in $\mathbf{1 8 1 4}$}

Riksforsamlingens forhandlinger. 1914, vol 1. Grøndahl \& søns boktrykkeri, Kristiania Riksforsamlingens forhandlinger. 1916, vol 3. Grøndahl \& søns boktrykkeri, Kristiania

\section{Records of the Norwegian Parliament and Extraorinary Parliament, Royal Propositions}

Det overord. St. Forh. (1814)

St. Forh. 1821, vol. 7

St. Forh. 1824, vol. 2

Storthingstidende (1878), vol. 2

Indst. O. IV. (1878)

Sth. Prp. No. 20 (1881)

\section{Court Decisions}

5 U.S. 137 (1803) Marbury v. Madison

Judement of the Norwegian Supreme Court on November 1, 1866. In: Ugeblad for lovkyndighed, statistik og statsøkonomi, vol 6. 1866-1867, 165-174 


\section{Records of the Court of Impeachment in 1883-1884}

Rigsrets-Tidende. 1883-1884 (3 Vols), vol 2. Th. Steens Forlags-Expedition, Kristiania Dokument nr. 1 (1930) Voteringer i Riksrettene 1814-1884

\section{Treaties}

The treaty of Kiel between the king of Sweden and the king of Denmark and Norway, signed on January 14,1814

\section{Constitutions, Norway}

The Norwegian constitution of 1814 , as adopted on May 17

The Norwegian constitution of 1814, as revised on November 4

English translation of the Norwegian constitution of 17 May 1814: The Constitution of the Kingdom of Norway. Jacob Lehmann: Christiania 1814

Official translation of the current constitution of Norway: https://stortinget.no/globalassets/pdf/ english/constitutionenglish.pdf. Accessed 16 Sept 2016

\section{Constitutions}

The constitution of Virginia of 1776, including the Bill of Rights

The constitution of Massachusetts of 1780

The constitution of South Carolina of 1790

The French constitution of 1791

The constitution of New Hampshire of 1792

The constitution of Batavia of 1798

The French constitution of 1799

The Spanish constitution of 1812

The French constitution of 1814, La Charte Constitutionnelle

The constitution of Baden of 1818

The constitution of Bavaria of 1818

The constitution of Württemberg of 1819

The constitution of Hesse-Darmstadt of 1820

The constitution of Saxe-Coburg-Saalfeld of 1821

The constitution of Saxony of 1831

The constitution of Hesse-Cassel of 1831

The constitution of Belgium of 1831

The constitution of Brunswick of 1832

The constitution of Hohenzollern-Sigmaringen of 1833

The constitution of Hanover of 1833

The constitution of Italy of 1848, Statuto Albertino

The constitution of Denmark of 1849 
Open Access This chapter is licensed under the terms of the Creative Commons Attribution 4.0 International License (http://creativecommons.org/licenses/by/4.0/), which permits use, sharing, adaptation, distribution and reproduction in any medium or format, as long as you give appropriate credit to the original author(s) and the source, provide a link to the Creative Commons license and indicate if changes were made.

The images or other third party material in this chapter are included in the chapter's Creative Commons license, unless indicated otherwise in a credit line to the material. If material is not included in the chapter's Creative Commons license and your intended use is not permitted by statutory regulation or exceeds the permitted use, you will need to obtain permission directly from the copyright holder.

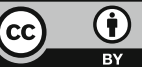

